\section{ENROLLMENT ON INTEGRATION PROCESS OF NATIONAL HEALTH ASSURANCE IN INDONESIA}

\section{JKMA}

Jurnal Kesehatan Masyarakat Andalas diterbitkan oleh:

Program Studi S-1 Kesehatan Masyarakat Fakultas Kesehatan Masyarakat Universitas Andalas p-ISSN 1978-3833 e-ISSN 2442-6725

$11(2) 65-66$

@2017 JKMA

http://jurnal.fkm.unand.ac.id/index.php/jkma/

\begin{abstract}
Meita Veruswati ${ }^{1,2,3} \otimes$, Al Asyary ${ }^{1,2}$
${ }^{1}$ Department of Public Health Sciences, University of Muhammadiyah Prof Dr Hamka (UHAMKA)

${ }^{2}$ Problem Solving for Quality Hospitals (PSQH) Unit, Center for Educational and Public Services, Faculty of Public Health, University of Indonesia

${ }^{3}$ Tobacco Economics Unit, Demographic Institutes, Faculty of Business and Economics, University of Indonesia (LD FE-UI)
\end{abstract}

It estimated that Indonesian's single national health insurance namely JKN (Jaminan Kesehatan Nasional) program, enables several aspects shifting to health system in Indonesia, including financing management, healthcare management, information management, stakeholders' coordination, etc. Otherwise, JKN system forecasts to influence other factors beyond the health system itself, such as (a) economics aspect including business climate, employment, and payment system; (b) poverty alleviation; (c) social protection; and (d) registry and residential data systems.

Since 2014, JKN covered 48.2\% of Indonesian society who have registered to this scheme or JKN. ${ }^{(1)}$ Once Social Insurance Committee for Health (BPJS Kesehatan) acted as managing board for this program, it regulated that all of Indonesian society have to be enrolled with this scheme at beginning of 2019.(2) However, each of region either municipalities or provinces had already applied their regional health assurance (Jaminan Kesehatan Daerah/Jamkesda) for their communities by their selves. ${ }^{(3)}$

Furthermore, all provinces in Indonesia had implemented their Jamkesda by their selves, which were four provinces that achieved UHC for all of their population. There were 27 (81.81) provinces exempted out-off-pocket health packages for their poor residences, while other two (6.06\%) provinces allowed incapability-confirmed letter (Surat Keterangan Tidak Mampu/SKTM) to freeing healthcare for their poorest residences. ${ }^{(4,5)}$ Thus, local government capability differed one to another for implementing the Jamkesda anyway, particularly in achieving UHC for each of their residences.

From $1^{\text {st }}$ January 2014, JKN participants consisted of either from all of central governments to local governments' health insurances that included national public health insurances (Jamkesmas), civil servants' health insurance (Askes PNS), militaries' health insurance (Jaminan Kesehatan $\mathrm{TNI}$ Polri), and employments' social insurance (Jamsostek). Otherwise, BPJS Kesehatan opened the registration to each of person who wants to register on it as well as either for independent, corporate, or for incapable polis insurance (Penerima Bantuan Iuran/PBI). It estimates that 110.4 million (48.2\%) of Indonesian society were registered as JKN polis in January 2014. ${ }^{(6)}$ While President Act of Indonesian Regulation was amended that all of Indonesian society should be registered as JKN polis on 2019..$^{(4,5)}$

At least, there were several matters to consider on formulating integration policy as follows: ${ }^{(4,5)}$ (1) Existing regulation and/or action plan on each provincial level, that will be determined how the integration process would be well-implemented; (2) Political commitment of local government, which indicated that it depend on each conflict of interests; (3) Field readiness, that also developed as key factor to well-prepare the integration progression, included accessibility, healthcare facilities, as well as knowledge and awareness level of population; (4) Regional capacity, that linked to another policy such as regional 
middle-term development planning (Rencana Pembangunan Jangka Menengah Daerah/RPJMD). In fact, it is important to remind that each regional achievement should be relied on RPJMD; (5) Economic and monetary factors, particularly regional fiscal preparedness' that would be determined its appropriateness; and (6) Result based financing, that enabled to bridging the existing system difference and increased performance either on supplies or demands sides of health system strengthening towards UHC in Indonesia.

Unfortunately, several policies and central regulations tend to arrange without any following technical guideline ${ }^{(7)}$, including JKN enrollment procedures the world 2019 fourth most populous country, declared that it would provide affordable health care for all its citizens within seven years. $(8,9)$ This crystallised an ambition first enshrined in law over five decades earlier, but never previously realised. This paper explores Indonesia 2019 journey towards universal health coverage (UHC). A trouble emerged when poorest population assigned as independent's JKN polis and they planned to exchange their polis status into PBI's JKN then. This unknown procedure is not regulating in central government. In fact, several regions have implemented it anyway such as Bogor City. It is essential to regulate its integration as well as for poor community's data arrangement and integrating and cleaning participants' data before it send to BPJS so it prevents rollback and incomplete data to local government.

\section{References}

1. Mboi N. Indonesia: On the Way to Universal Health Care. Heal Syst Reform [Internet]. 2015;1(2):91-7. Available from: http://www. tandfonline.com/doi/full/10.1080/2328860 4.2015.1020642

2. BPJS. Undang-Undang Republik Indonesia Nomor 40 Tahun 2004 tentang: SJSN (Sistem Jaminan Sosial) dan Undang-Undang Republik Indonesia Nomor 24 Tahun 2011 tentang: BPJS (Badan Penyelenggara Jaminan Sosial). Jakarta: BPJS; 2004.

3. Aulia P. Polemik Kebijakan Integrasi Jaminan Kesehatan Daerah Ke Sistem Jaminan
Kesehatan Nasional. J Kesehat Masy Andalas. 2014;8(2):93-9.

4. Supriyantoro S, Hendarwan H, Savithri Y. Analisa Kesiapan Integrasi Jaminan Kesehatan Daerah (Jamkesda). J Ekol Kesehat. 2014;13(3 Sep):179-89.

5. Supriyantoro S, Hendarwan H. A Case Study on the Implementation of Local Health Insurance Benefit Packages. Bul Penelit Sist Kesehat. 2014;17(4 Okt):327-36.

6. Widodo J. President of Republic Indonesia's Speech: Badan Perencana Pembangunan Nasional/Kementerian Perencanaan Pembangunan Nasional. Bappennas/KemenPPN RI; 2014.

7. Veruswati M, Asyary A. Implementation of Information System Towards Health System Strengthening in Indonesia: A Policy Brief. Public Heal Indones. 2017;3(3):73-6.

8. Pisani E, Olivier Kok M, Nugroho K. Indonesia's road to universal health coverage: a political journey. Health Policy Plan. 2016;0(0):110.

9. Guinto RLLR, Curran UZ, Suphanchaimat $\mathrm{R}$, Pocock NS. Universal health coverage in "One ASEAN": Are migrants included? Glob Health Action. 2015;8(1). 